\section{Медицинский туризм - бизнес на путешествиях с пользой для здоровья}

Одним из перспективных и быстрорастущих секторов туристического бизнеса является медицинский туризм - путешествия с целью оздоровления и получения медицинских услуг за пределами региона постоянного проживания В ведущих странах это направление развивается давно и успешно. Санатории В ведущих странах это направление развивается давно и успешно. Санатории и клиники Швейцарии, Германии, Италии принимали состоятельных пациентов со всей Европы еще в XVIII в. А в последние годы наряду с традиционными направлениями оздоровительного отдыха $и$ санаторно-лурортного лечения растут популярность и экономинеская значимость сектора тури -

Слючевы слова: медицинский туризм, туристический бизнес, оздоровительные услуги, санатории

\section{Перспективный сектор}

Рынок медицинского туризма сегодня считается одним из самых динамичных секторов экономики. Согласно докладу на Международном конгрессе по медицинскому туризму в 2013 г. (Нью-Дели, Индия), доходы от него выросли с 40 млрд долл. в 2004 г. до 500 млрд в 2012 г., что составляет 14\% общих доходов от туризма, или 1,8\% мирового ВВП [1]. По мнению авторов доклада, в 2013-2017 гг. этот сектор туризма будет расти в среднем на $9,9 \%$ в год, что почти в два раза выше, чем в целом по отрасли, и к 2017 г. достигнет 678,5 млрд долл., или 16\% общего объема доходов от туризма. Не случайно сегодня более 50 стран заявляют о развитии медицинского туризма на уровне государственной политики.

Принято различать медицинский и оздоровительный туризм. Первый предполагает получение высокотехнологичной медицинской помоши (в условиях стачионара или медииинского иентра), второй - общее оздоровление в условиях курортной местности. Многие страны, проявляюшие активность на рынке медицинского туризма, стараются развивать оба направления комплексно, открывая новые высокотехнологичные клиники поблизости от курортных зон или на их территории.

Одной из главных причин активного развития медицинского туризма является значительная разница в уровне здравоохранения и стоимости лечения в разных странах. Так, пациенты, не имеющие возможности получить определенную процедуру или услугу у себя на родине или не желающие тратить время на ее ожидание, нередко находят аналогичные услуги за границей, часто - по более низкой цене и без промедления.

Не случайно основными поставщиками клиентов для индустрии медицинского туризма являются Европа и Северная Америка, где высокий уровень развития медицинских технологий сочетается с не менее высокой стоимостью медицинских услуг Так, в 2012 г. потребители из пяти стран - США, Германии, Японии, Франции и Австрии - обеспечили 63\% мирового спроса на зарубежные медуслуги.

Данные исследований McKinsey [2] по итогам опроса потребителей медицинского туризма из нескольких стран (цифры усредненные) свидетельствуют о том, что основные мотивы потребителей медицинского туризма - необходимость получения высокотехнологичной помощи (42\% опрошенных), поиск медицинских услуг более высокого качества (33\%), необходимость срочной помощи (15\%) и желание сэкономить на лечении. А наиболее востребованные услуги - снижение веса (32\%), ортопедия $(22 \%)$, косметология $(12 \%)$ и заболевания позвоночника $(2 \%)$.

Перечень наиболее активно принимающих стран постоянно пополняется по мере развития национального здравоохранения и реализации программ, стимулирующих развитие медицинского туризма. В 2012 г. первую десятку стран-лидеров составили Индия, Венгрия, Мексика, Сингапур, Тайланд, Барбадос, Бразилия, Израиль, Южная Корея, Турция [3]. Только Индия в указанный период оказала медицинские услуги иностранным туристам на сумму 2,3 млрд долл. Во всех названных государствах стоимость медицинских услуг намного ниже, чем в США и ведущих странах Европы, а количество клиник, сертифицированных по международной системе Joint Commission International (JCI), постоянно растет (как правило, при поддержке государства).

Независимо от степени коммерциализации медицинского сектора в разных странах, определяющая роль в развитии медицинского туризма как отрасли принадлежит именно государству. Оно влияет не только на уровень национальной высокотехнологичной медицины (напрямую - через развитие государственных клиник, или косвенно - через стимулирование и поддержку развития 
частных медцентров), но и формирует специальное законодательство, занимается становлением общей принимающей инфраструктуры (дороги, гостиницы, таможня и т. д.), без чего системное развитие принимающего медицинского туризма невозможно.

Например, такая программа, разрабатываемая в Южной Kopeе, предусматривает упрощение правил въезда в страну по «медицинским турам», стимулирование инвестиций в медицинские компании, улучшение транспорта и условий размещения, подготовку специалистов в области управления и продвижения за рубежом медицинских услуг и т. п. Государство даже берет на себя страховые риски по медицинскому обслуживанию иностранцев. Южнокорейское правительство рассчитывает, что эти меры позволят увеличить поток въездного медицинского туризма до 1 млн человек в 2020 г. против 500 тыс. в 2012 г.

Туристическое управление Тайланда разработало программу продвижения медицинского туризма специально для граждан России и стран СНГ, делая основной упор на полную диагностику в клиниках с русскоязычным персоналом по ценам «как для своих». Так, по данным Medical \& Health Tourism Magazine, уже сегодня некоторые тайские клиники обслуживают исключительно зарубежных пациентов, в других доля иностранцев составляет 30-50\%. По итогам 2012 г. эту страну с медицинской целью посетили 1,85 млн иностранцев, совокупный доход тайских медицинских клиник составил более 2 млрд долл. [4].

Израиль, Корея, Турция, Тайланд, Китай и другие страны активно продвигают на зарубежных рынках услуги своих высокотехнологичных клиник, намереваясь превратить медицинский туризм в значимый сектор национальной экономики.

\section{Что лечат в России иностранцы}

В России, несмотря на наличие высокотехнологичных медицинских центров, в том числе - мирового уровня, пока только намечаются некие зачатки медицинского туризма. Это направление развивается у нас стихийно, и все истории успеха случаются не столько благодаря, сколько вопреки государственной политике в области здравоохранения и туризма, которые, кстати, находятся в ведении разных министерств.

Первопроходцами российского принимающего медтуризма стали частные стоматологические клиники, оказывающие услуги бывшим соотечественникам, уехавшим за рубеж. Уже с конца 1990-х годов эмигранты нередко использовали визиты к родственникам для того, чтобы «попутно» подлечить зубы, поскольку цены даже в самых статусных и современных российских стоматологических клиниках в 3-5 раз ниже, чем в Европе или Америке.

К слову, разница в ценах на медицинские услуги стимулирует и внутренний медицинский туризм в нашей стране. Так, по данным СМИ, жители Москвы и Санкт-Петербурга в условиях последнего кризиса часто выбирали для лечения медицинские центры соседних регионов - Тулы, Твери, Нижнего Новгорода где стоимость услуг в среднем на 40\% ниже, чем в столичных клиниках [5]. Массовым спросом пользуются у российских туристов стоматологические, косметологические, гинекологические и некоторые другие платные услуги, цены на которые могут существенно различаться в разных регионах. К примеру, стоимость операции экстракорпорального оплодотворения в российских клиниках колеблется от 15000 руб. до 2500 долл. (без стоимости лекарств) [6].

Стало массовым явлением посещение России с целью получения медицинской помощи женщинами из бывших советских республик - Таджикистана, Узбекистана, Туркмении, Киргизии на последних сроках беременности, чтобы родить в комфортных условиях и под надежным врачебным присмотром. Такие пациентки, как правило, не имеют медицинской карты, не говоря уже о страховом полисе, нередко страдают хроническими заболеваниями, но отказать им в предоставлении экстренной медицинской помощи, к которой относится родовспоможение, российские врачи не могут. Причем зачастую эта помощь оплачивается из местных бюджетов. Так, по данным московского правительства, на экстренную помощь и лечение мигрантов столичный бюджет расходует ежегодно около 5 млрд руб. [7] Аналогичные расходы Новосибирской области в 2010 г. составили 1,87 млн руб. [8].

\section{Что лечат россияне за границей}

Нельзя сказать, что выездной медицинский туризм в России пользуется большой популярностью, так как стоимость оздоровительного тура в среднем в 1,3 раза выше, чем обычной путевки, 
а высокотехнологичная помощь за рубежом может быть дороже в разы (рисунок).

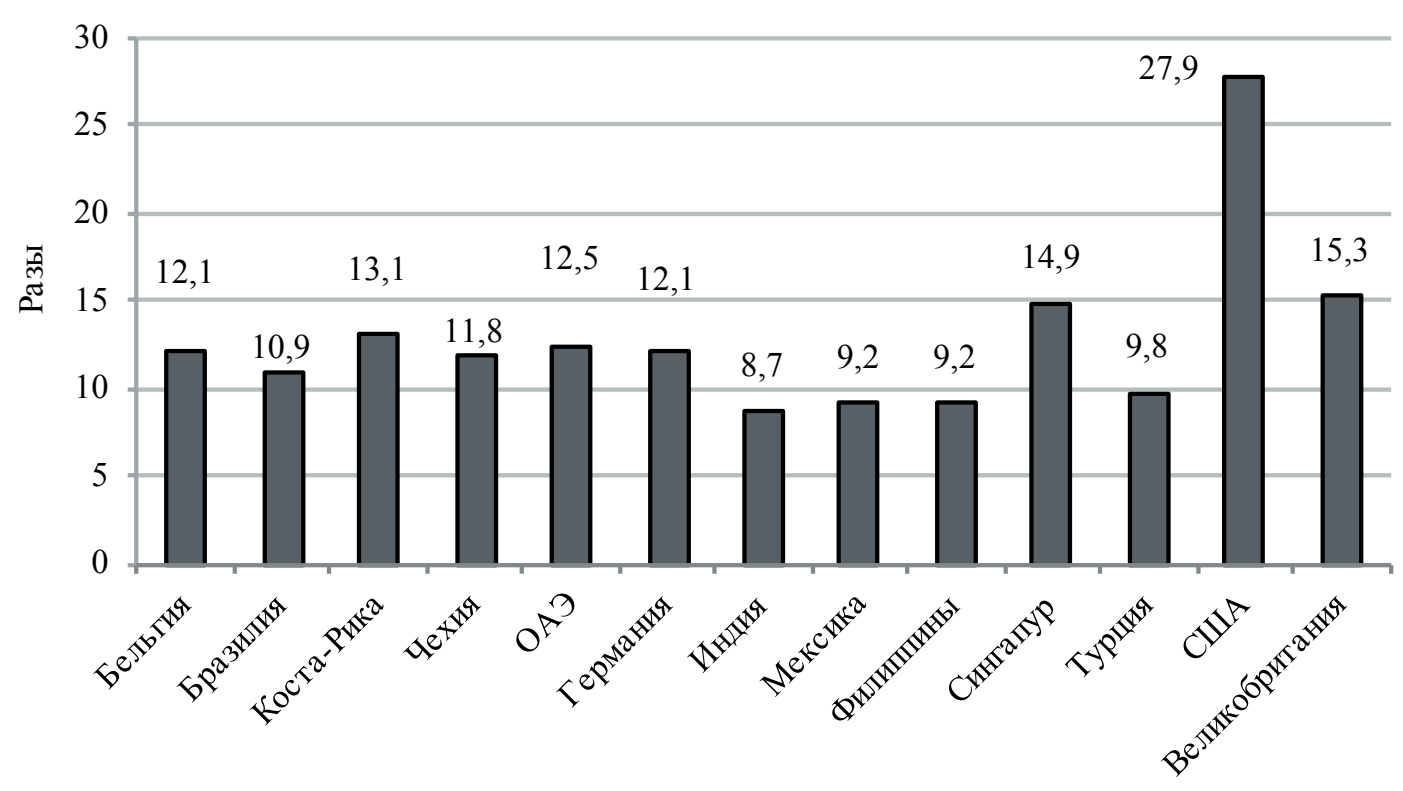

Источник: [9]

Увеличение стоимости оказания

медицинской помощи в некоторых странах мира

по сравнению с Россией, раз

Так, по данным Ассоциации туроператоров России (АТОР), доля «медицинских туров» в общем количестве проданных заграничных путевок из года в год не превышает $1-1,5 \%$. Наибольшей популярностью пользуются санаторно-курортный отдых, некоторые виды высокотехнологичной помощи и так называемый чек-ап ${ }^{1}$. Как видим, «оздоровительный» и «медицинский» туризм не всегда различаются экспертами при оценке рынка.

Большинство медицинских туристов из России традиционно отправляются в Израиль (45\%) и Германию (20\%). Во многом это объясняется отсутствием языкового барьера: в клиниках названных стран трудится немало мигрантов из стран СНГ, а когда речь идет о взаимодействии врача и пациента, язык очень важен. Об экономии средств, естественно, речь не идет. Впрочем, в последние годы наметился рост популярности и других направлений: Турция, Сингапур, Швейцария, Франция и страны Восточной Европы. Наиболее востребованы процедуры в таких

${ }^{1}$ Check-up (чек-ап) - комплексное обследование с целью ранней диагностики и профилактики заболеваний. областях, как кардиохирургия, трансплантология, глазная хирургия, онкология, а также лечение хронических заболеваний, которое требует наличия современных технологий и специализированного послеоперационного ухода [9].

По сообщениям СМИ, в последние годы резко возрос поток россиян, отправляющихся с медицинскими целями в Китай. Отдельные клиники приграничных регионов принимают до $80 \%$ россиян, привлекаемых хорошим соотношением «цена - качество услуг» и короткими сроками диагностики и лечения. Ориентируясь на пациентов из России, некоторые китайские клиники даже обзаводятся штатом переводчиков, расширяют спектр услуг [3], а в 2011-2013 гг. была отмечена целая волна появления новых частных клиник «традиционной медицины», ориентированных именно на российских пациентов. Обычно люди просто выезжают по турпутевке в Китай, а там уже обращаются в медицинские учреждения. Очень часто такие туристы сочетают лечение с шопингом, стремясь компенсировать затраты на путевку.

\section{Первые шаги на пути}

\section{к цивилизованному рынку медтуризма}

Наличие в нашей стране сети хорошо оборудованных клиник и медицинских центров могло бы стать основой для развития полноценного сектора медицинского туризма, пусть даже на первых порах внутреннего или ориентированного на ближнее зарубежье. Правда, это потребует известных изменений в принципах организации работы медицинских учреждений, но при очень большом желании можно обойтись даже без кардинальных реформ, в рамках существующего законодательства и с использованием государственно-частного партнерства. Об этом свидетельствует опыт Новосибирского НИИ травматологии и ортопедии (НИИТО) им. Я. Л. Цивьяна, сумевшего за четыре года увеличить объемы оказания медицинской помощи более чем в 10 раз.

Имея статус федерального государственного бюджетного учреждения, НИИТО стал одним из основателей Инновационного медико-технологического центра (ИМТЦ, или Медицинский технопарк) [10]. Это позволило институту расширить перечень услуг и внедрить принципиально новые для российского здравоохранения принципы организации медпомощи. 
«Мы взяли за образец опыт клиники Майо в Рочестере (США), которая впервые сумела выстроить всю систему работы - от постановки диагноза до определения алгоритма лечения и логистики между различными службами - “вокруг пациента”, рассказывает директор ФГБУ «НИИТО», д. м.н. М.А. Садовой. Пациенту достаточно обратиться в клинику, и дальше не его забота - увязать всех необходимых специалистов, лабораторные анализы, лечебные процедуры и т. д. Оказалось, это именно то, что нужно пациентам, и очень многие состоятельные люди готовы платить за это деньги. В результате эта маленькая провинциальная больница превратилась в градообразующее предприятие - крупнейший медицинский центр, в котором ежегодно оперируются и лечатся более 500 тыс. человек не только со всей Америки, но из Европы и даже из России».

В нашей стране реализовать такой подход в полной мере невозможно не только потому, что принятая в России система бюджетно-страховой медицины предполагает закрепление пациентов за определенными медучреждениями «по прописке». Проблема в том, что отечественная система здравоохранения в целом плохо сбалансирована. Российские медучреждения в основной своей массе ориентированы на какой-то определенный сегмент лечебного процесса - диагностику, консервативное или оперативное лечение, реабилитацию или восстановительное лечение. А разделение медучреждений на федеральные, региональные, ведомственные, частные - с различными принципами и источниками финансирования, разными организационными подходами к управлению, ведению пациентов, диспетчеризации и т. д., отнюдь не добавляют системе стройности и прозрачности.

«Если высокотехнологичная медицинская помощь у нас в стране развита относительно неплохо по сравнению даже со многими европейскими странами, и ее часто получают быстрее, чем, например, в Великобритании или США, то в том, что касается консервативных методов лечения, чек-апов и ведения пациентов, мы сильно отстаем от передовых стран, - рассуждает М.А. Садовой. - Тот факт, что состоятельные россияне все чаще едут на диагностику в Германию, Израиль, Корею, Китай, во многом связан с тем, что у нас нет эффективных систем, которые бы работали “вокруг пациента”. Разве что в некоторой степени частные клиники, но, как правило, это клиники одной технологии, в которую они и пытаются “впихнуть” всех подряд, чтобы заработать, так что в частном секторе нередко возникает определенный конфликт интересов. В странах, развивающих медицинский туризм, тоже работают частные клиники, но они зарабатывают за счет объемов и потому стремятся сделать так, чтобы было удобно пациенту. Им выгодно избавить его от лишних исследований, чтобы не перегрузить финансово, и при этом выдать диагноз максимально быстро и точно. У нас же пока игра идет на стоимости...».

НИИТО в связке с ИМТЦ попытался внедрить в свой рабочий процесс отдельные подходы клиники Майо. «Был типичный советский хирургический институт с набором небольшого количества технологий, на суперпрофессиональном уровне, - вспоминает М.А. Садовой. - В какой-то момент мы обратили внимание, что эффективность лечебного процесса страдает из-за того, что диагностика и реабилитация выпадают из-под нашего контроля И мы решили замкнуть процесс на себя. Создали мощное диагностическое подразделение в двух направлениях - с одной стороны НИИТО как федеральный центр, с другой - медицинский технопарк как подразделение, где развиваются инновационные технологии, включая диагностику и реабилитацию. При этом важно, что все ключевые диагностические лаборатории - ИКТ, MРТ, рентген, УЗИ и т. д. - находятся в одном месте. Это и время обследования сокращает, и врачи могут взаимодействовать, консультироваться с коллегами во время установления диагноза На базе диагностического отделения появилась большая поликлиника на 200 тыс. человек в год. Если пациенту показано оперативное вмешательство, он попадает либо в систему НИИТО с его федеральными квотами, либо мы пытаемся сформировать для него трассу вариантов платного лечения. Далее - реабилитация. Раньше мы выпускали пациента после операции, условно говоря, “в никуда" - где хочешь, там и реабилитируйся, сейчас на базе технопарка создали серию реабилитационных клиник, в которых пациент находится после операции 1-2 недели. Затем следует система диспансеризации, которая также осуществляется на нашей базе. Сейчас мы пытаемся закрыть реабилитацию и консервативное ведение больных вне клиники с помощью дистанционных технологий. Реабилитация в стационаре сегодня обходится в 5-10 тыс. руб. в день. В ИМТЦ разработан аппарат, 
который позволит лечить пациента за тысячу рублей в день на дому. Уже получено разрешение, идет апробация технологий, с 2016 г. начнется активное производство».

В результате за последние пять лет количество консультаций выросло с 20 до 200 тыс. в год, операций - с 2 тыс. до 12 тыс., число обследованных больных - с 10 тыс. до 130 тыс. В новосибирскую клинику приезжают пациенты из 67 регионов РФ. При этом часть важнейших функций - по разработке и внедрению новых технологий, участию в венчурных проектах, оказанию широкого спектра платных услуг сверх программы госгарантий выполняет частный технопарк.

«В рамках обычной бюджетной государственной структуры все это организовать было бы нереально, - признается М. А. Садовой. - Госструктура работает по Бюджетному кодексу. Например, чтобы в институте поставить даже автомат по продаже бахил, нужно получить разрешение в Минздраве, провести торги и т. д. Есть ограничения по фонду оплаты труда, по покупке новой техники, апробированию новых технологий. Поэтому все, что касается бюджета, мы делаем через институт - с максимальной эффективностью, а все инновационные, коммерческие вещи реализуются в рамках государственно-частного партнерства через технопарк. Это дает нам определенную степень организационной и финансовой свободы».

Примечательно, что, наращивая объем услуг, в том числе платных, институт постоянно работает над снижением их себестоимости. Если в государственных клиниках аналогичного профиля стоимость лечения одного больного составляет в среднем 42-44 тыс. руб., в НИИТО - всего 11 тыс. К тому же более половины пациентов лечатся по программе ОМС.

«Мы нашли источники бюджетного финансирования для каждого этапа в лечебном процессе. Например, если пациент попадает в НИИТО по скорой помощи, его обследуют в диагностическом центре за счет регионального ФОМС, затем, если необходимо хирургическое вмешательство - оперируют по федеральной квоте, если нет, он получает консервативное лечение в стационаре технопарка, опять же за счет ФОМС Новосибирской области. То же с реабилитацией, вплоть до изготовления корсета - мы закрыли всю цепочку», - утверждает М.А. Садовой. Другое дело, что кому-то требуются услуги сверх программы госгарантий, кто-то не хочет ждать квоту. Они могут получить медпомощь на платной основе.

«Если бы еще государство более активно помогало с точки зрения стимулирования добровольного медицинского страхования или развития системы “ОМС+", когда пациент может приобрести дополнительный полис, гарантирующий более дорогостоящее лечение, можно было бы сделать платные услуги доступными для гораздо большего количества граждан», - полагает М.А. Садовой.

Новая система взаимоотношений и взаимодействий внутри партнерства потребовала создания системы управления, кардинально отличающейся от той, что сегодня есть в российском здравоохранении. «Управление осуществляется через сеть комитетов, отвечающих за различные направления деятельности, - поясняет директор НИИТО. - Есть комитет по хозяйственной части, по сестринскому персоналу, по врачебным решениям, по неотложной помощи и т. д. Ежедневно их руководители собираются и обсуждают, что происходит, какие назрели или проявились проблемы и как совместными усилиями их решить».

Проблемы и задачи возникают самого разного рода. От покупки нового оборудования до изменения графика работы хирургического отделения. «Мы ищем возможности для увеличения количества операций. Сейчас оперируем в неделю 300 больных на 260 койках, это самый высокий показатель в России, но мы хотим его улучшить, потому что потребность в такой помощи очень велика, - объясняет М.А. Садовой. - Тут есть как минимум два пути. Во-первых, можно увеличить операционное время в одну рабочую смену: скажем, начинать операции не в 8.30, а в 7.15 утра. Во-вторых, можно перейти на семидневную рабочую неделю. В российских клиниках по субботам и воскресеньям (а и иногда - и по пятницам) больные обычно не оперируются, но объективных причин для этого нет - просто сложившаяся практика. Мы хотим от нее отойти. Понятно, что такого рода изменения отразятся на работе абсолютно всех служб и подразделений, поэтому процесс довольно непростой и небыстрый».

Другой амбициозный проект НИИТО - создание промышленного производства керамических протезов на условиях концессии [11]. Общая стоимость проекта оценивается в 650 млн руб. (в ценах 2015 г.), из которых частный партнер должен вложить 
не менее 335 млн руб. в оснащение предприятия. При этом институт готов поделиться с будущим концессионером своими научными разработками, которые можно запустить в серийное производство, и он же обеспечит гарантии сбыта большей части производимой продукции. «За год у нас ставится 70 тысяч протезов. Практически все - импортные», - рассказывает М.А. Садовой. Единственный протез отечественного производства, используемый в практике НИИТО, - это пока первые опытные образцы керамических протезов, созданных новосибирским ЗАО «НЭВЗ-Керамикс», также в тесном сотрудничестве с НИИТО и ИМТЦ. К концу 2016 г. «НЭВЗ-Керамикс» планирует производить 20 тыс. таких протезов, но это закрывает только 50\% потребности института.

\section{Передовой опыт - в широкую практику}

По мнению М.А. Садового, при наличии в Новосибирске таких крупных и авторитетных научно-клинических организаций, как НИИ патологии кровообращения им. Е.Н. Мешалкина, Федерального центра нейрохирургии, НИИ туберкулеза, СОМС ФМБА, ряда уникальных федеральных клиник СО РАМН, регион при желании вполне мог бы превратиться в «сибирский Ричмонд» - значимый центр медицинского туризма с соответствующим сервисом. По крайней мере, опыт НИИТО показывает, что даже при существующих правовом поле и принципах финансирования можно найти возможности для весьма значительного расширения медицинской практики без ущерба для ее качества.

«Главное - правильно поставить задачу. Если задаться целью подвести под “чек-ап”, скажем, 10000 человек в год и сформировать под это систему, которая будет работать на пациента, это можно сделать в Новосибирске очень быстро, - рассуждает М.А. Садовой. - У наших клиник есть для этого классные специалисты, современное оборудование, хорошая репутация. Единственное, чего не хватает, - инициативы. Если выделить в составе крупного многопрофильного центра специальную структуру, заточенную на качественный, мирового уровня “чек-ап”, который бы подводил пациентов к оптимальной для них амбулаторной составляющей (или сделать это, например, на принципах кооперации разных клиник) - мы бы получили качественный скачок в деле оказания медицинской помощи и развития медицинского туризма. Решение проблемы с диагностикой сильно облегчило бы работу всем, и нам в том числе (у нас большая очередь на хирургическое лечение, на эндопротезирование). Но такой диагностический центр должен быть выведен из-под жесткого бюджетного пресса. Например - в рамках государственно-частного партнерства. При этом частная составляющая должна быть не менее 70\%, как показывает опыт».

Однако в целом в профессиональном сообществе нет единого мнения по поводу развития медицинского туризма в России.

Так, по мнению медиков, даже для внутреннего медицинского туризма может стать препятствием недавнее изменение порядка финансирования медицинского тарифа. С 1 января 2015 г. медицинский тариф возмещается территориальному ФОМСу той территорией, из которой приехал пациент [12]. Регионы теперь не захотят выпускать пациентов за свои пределы, хотя это далеко не всегда соответствует интересам последних, поскольку качество услуг «у соседей» может быть выше.

Отдельных мер требует развитие инфраструктуры, предназначенной для приема и обслуживания приезжих пациентов и сопровождающих их лиц. Например, гостиниц, способных принимать инвалидов-колясочников, крайне мало даже в Москве, не говоря уже о регионах.

Еще одна сдерживающая причина - невысокий уровень квалификации врачей. Высококлассные специалисты, к которым пациенты захотели бы приезжать из других регионов и стран, даже в крупных городах - наперечет. И, как правило, все они сильно загружены, совмещая работу в государственных клиниках где нарабатывается необходимый опыт и повышается квалификация, с несравнимо лучше оплачиваемой работой в частных медцентрах, цены которых недоступны большинству пациентов. Поэтому довольно сложно поддерживать профессиональный тонус на должном уровне. А услуги клиник и врачей «среднестатистического» уровня способны привлечь «медтуристов» разве что из беднейших республик Средней Азии.

Даже сами россияне не слишком высокого мнения о качестве национального здравоохранения. Так, по данным «ЛевадаЦентра», число сограждан, недовольных работой российских медиков, заметно превышает количество людей, положительно 
оценивающих их работуㄹ. Уровнем получаемых медуслуг оказываются удовлетворены либо те, кто реже других обращается к врачам, в силу своего возраста и состояния здоровья, либо те, кто с большой долей вероятности пользуется услугами частных клиник. Очевидно, что при отсутствии широкой сети медицинских центров, подобно НИИТО, реализующих эффективные проекты государственно-частного партнерства, основным драйвером развития высокотехнологичного медицинского туризма в России станет именно частный сектор здравоохранения, со всеми его специфическими рисками и внутренними конфликтами. Между тем грамотная государственная политика в сфере медицинского туризма могла бы способствовать более цивилизованному и сбалансированному развитию этого сектора.

\section{Не вполне медицина, но все же оздоровление}

Другое наиболее вероятное направление развития медицинского, а точнее, оздоровительного туризма в России - санаторно-курортное лечение. Обширная сеть санаторно-курортных учреждений, доставшаяся России в наследство от СССР и считавшаяся когда-то лучшей в мире, создавалась именно для лечения и профилактики различных заболеваний. Это была полноценная отрасль с единым управлением и регулированием, с собственной научной базой, системой подготовки кадров и т. д. До сих пор санаториями управляют главные врачи, а их деятельность лицензируется и курируется структурами Минздрава. В советское время санаторно-курортные учреждения были закреплены за различными ведомствами или предприятиями, которые их содержали, развивали и поставляли основную массу клиентов. В период реформ прежняя система финансирования и распределения путевок была разрушена, санаторно-курортная сеть перестала существовать как система.

Часть старых санаториев (по некоторым оценкам - до 30\%) закрылась, не найдя инвестиционных ресурсов на развитие. Например, старейший сочинский санаторий им. Орджоникидзе

${ }^{2}$ Опрос проводился 21-24 сентября 2012 г. по репрезентативной всероссийской выборке городского и сельского населения среди 1601 человека в возрасте 18 лет и старше в 130 населенных пунктах 45 регионов страны. Распределение ответов приводится в процентах от общего числа опрошенных. Статистическая погрешность не превышает 3,4\% [13] .
(16 га земли, 9 корпусов на 640 мест) практически утратил лечебную базу. Просуществовав до 2010 г. в качестве сначала ФГУП, затем ОАО со 100\%-м государственным участием, он в итоге был закрыт «в связи с обветшанием номерного фонда», коллектив уволен, ОАО ликвидировано. Лишь спустя три года нашлась некая кипрская компания, пообещавшая вложить в реконструкцию санатория 7,5 млрд руб., но к работам так и не приступила. А в мае 2014 г. несколько корпусов арендовала «на один-два сезона» компания «Ателика». На этот раз инвестор вложил 30 млн руб. в модернизацию, но от продвижения санаторно-лечебной базы (сероводородные ванны) отказался, сосредоточившись на чисто гостиничных услугах [14].

Некоторые здравницы, не имеющие собственных бальнеологических, природно-климатических ресурсов, по сути, превратились в спа-отели и рекреационные учреждения, в которых оздоровительные процедуры составляют далеко не основную часть услуг (например, санаторий «Магистраль» в Красноярском крае позиционирует себя как «центр деловых связей»). В то же время в традиционных курортных зонах за последние годы возникли новые гостиницы, дома отдыха, пансионаты и т. п., предлагающие некий набор оздоровительных или спа-услуг и на этом основании позиционирующие себя как санаторно-курортные организации, хотя на самом деле для получения такого статуса необходима лицензия «Росздравнадзора».

В результате сегодня у различных органов нет единства в оценке санаторного фонда. Так, «Росстат» в 2012 г. насчитал в России 1905 организаций (без учета микропредприятий) с коечным фондом в 420 тыс. мест. Чиновники Минздрава в тот же период заявляли о 1211 санаториях и пансионатов с общим фондом в 333196 коек.

Но на внешний рынок эта сеть практически не работает: изза длительного недофинансирования уровень комфорта и услуг заметно отстает от мирового, чего не скажешь об уровне цен, на которые влияют и сезонная неравномерность загрузки, и отсутствие конкуренции, и непродуманная налоговая политика Негативно сказываются на привлечении зарубежных гостей и языковой барьер, и в целом слабая информированность об услугах. Неудивительно, что в 2014 г. наиболее посещаемым иностранцами курортом России, по данным «Ростуризма», стал 
Сочи (в олимпийский год доля иностранных граждан составила порядка $25 \%$ от общего числа туристов), а наиболее востребованными услугами - осмотр олимпийского городка и экскурсии по окрестностям, но отнюдь не оздоровление.

У наших соотечественников отдых в России, в том числе оздоровительный, в 2014-2015 гг. стал пользоваться вынужденно большей популярностью, чем раньше, однако динамика рынка собственно санаторно-курортных услуг заметно отстает от общеотраслевой. Так, согласно оценке «Ростуризма», в 2014 г. количество туристических поездок внутри России выросло на 30-40\%, при этом, по данным BusinesStat, объем рынка санаторно-курортных услуг вырос всего на 1,6\% в натуральном выражении и на 9,5\% - в стоимостном, составив по итогам года 58,7 млн человеко-дней, или 109,7 млрд руб.

Официальной статистики за 2015 г. еще нет, но согласно опросу ВЦИОМ, проведенному после окончания летнего сезона отпусков, популярность у соотечественников курортов Краснодарского края выросла с 11\% до 14\%, Крыма - с 2\% до 6\% [15]. При этом каждый второй из 59\% опрошенных, взявших отпуск летом 2015 г., «не выезжал дальше дачи», что объясняется снижением реальных доходов россиян. И одна из причин - курорты, невзирая на объективные обстоятельства, повысили цены на путевки на 20-30\% относительно предыдущего года без адекватного роста качества и количества услуг. Свою лепту в повышение цен на путевки внесли и перевозчики, подняв тарифы, и целая армия посредников в лице турагентств и операторов ${ }^{3}$. Не отставали от коллег в стремлении заработать и рестораторы, и представители индустрии развлечений. В итоге $34 \%$ опрошенных ВЦИОМ отметили, что там, где они отдыхали, были слишком высокие цены.

\section{Санаторно-курортная сеть:}

\section{требуется срочная починка}

Между тем спрос на санаторно-курортное лечение у россиян по-прежнему высок. Так, по данным ВЦИОМ, не менее 27\% респондентов отмечают, что хотели бы отдыхать в санаториях на территории России (14\% делали это в последние 2-3 года).
Очевидно, что усилия всех сторон, заинтересованных в развитии этого направления, должны быть направлены на обеспечение действительно эффективных программ оздоровительного отдыха за приемлемые деньги. Только так можно будет поддержать вынужденный (пока еще) спрос и привлечь клиентов в будущем.

Здесь, по мнению представителей туристического бизнеса, очень многое зависит от системы распределения путевок, поскольку лечебных факторов, как и болезней, на которые они воздействуют, довольно много, и неспециалистам в них разобраться сложно. Сегодня, по информации Ассоциации туроператоров России, лишь 8-9\% клиентов выбирают санаторий по рекомендации лечащего врача. Между тем, коль скоро речь идет все-таки об оздоровлении, роль врачей в выборе санатория должна быть более весомой. «Только врач может порекомендовать тот или иной курорт в соответствии с медицинскими показаниями», подчеркнул глава комитета по внутреннему туризму И. Уманский, выступая на Международной конференции по формированию туристского продукта курортных территорий в Белокурихе 4 Иначе, приехав на тот или иной курорт, человек может узнать, что местные лечебные факторы для него не подходят, и вместо полноценного оздоровления ему приходится ограничиваться спа-услугами или просто отдыхом.

От этого проигрывают не только пациенты, но и здравницы, многие из которых по разным причинам (отсутствие средств, невыгодное расположение и др.) вынуждены ограничивать свою деятельность услугами медицинского характера. Разрушение централизованной системы распределения путевок сказывается на них порой просто губительно.

Так, в сложном положении оказался курортный комплекс «Аршан» (Республика Бурятия), находящийся в 240 км от Иркутска и 500 км от Улан-Удэ. Два крупнейших санатория комплекса - «Аршан» и «Саяны» - входят в структуру профсоюзного учреждения «Байкал-курорт», которое обеспечивает львиную долю клиентуры. В советское время санаторий имел федеральный статус, утраченный в эпоху реформ, и это вкупе с относительной удаленностью здравницы сильно затрудняет его загрузку. 
«Мощности санатория - около 1000 мест - в нынешней ситуации оказались избыточны, - объясняет представитель “Байкалкурорта". - И хотя за последние годы мы сократили номерной фонд примерно на четверть - из прежних секционных номеров сделали современные трехместные, часть выделили под детский лагерь, имеющиеся 762 места все равно заполнить непросто. С 2008 г. предприятия перестали заключать с нами договоры на оздоровление своих работников, то же самое по линии соцзащиты - детский лагерь пришлось сократить со 100 до 80 мест. В итоге среднегодовая загрузка снизилась с $80-90 \%$ до $60 \%$.

Даже при таком раскладе санаторию удается зарабатывать на текущее содержание, но на развитие ресурсов уже не остается. Проблема усугубляется возросшей конкуренцией с местным бизнесом. Хотя санаторий находится в заповедной зоне, и массового строительства гостиниц и пансионатов здесь не ведется, жители соседнего поселка охотно сдают отдыхающим комнаты, гостевые домики, и это оказывает заметное давление на цены санаторного комплекса.

По сути, единственным нашим конкурентным преимуществом является наличие квалифицированных медицинских услуг, и мы их развиваем по мере возможности. Например, у нас есть уникальный мастер по иглоукалыванию, он работает уже много лет, у него сложилась постоянная клиентура. Пытаемся подстроиться под особенности спроса - делаем краткосрочные программы на 2-7 дней пребывания, по некоторым программам принимаем пациентов без санаторно-курортной карты - диагностику и все назначения делаем у себя, перевели процедурные кабинеты на 7-дневную рабочую неделю. В этом направлении есть определенные успехи. Находятся и точки взаимодействия с местным бизнесом. Так, фирмы из близлежащего поселка организуют для клиентов санатория автобусные экскурсии по окрестностям, устраивают праздничные банкеты с живой музыкой».

По некоторым оценкам, подобные «Аршану» «некоммерческие» здравницы с государственной (региональной) и муниципальной формой собственности, составляют примерно $38 \%$ в структуре санаторного фонда. Подавляющее большинство из них функционирует по «госпитальному» принципу, оказывая преимущественно медицинские и ограниченный перечень прочих услуг. В современных экономических условиях эти учреждения оказались наиболее уязвимыми.

Около 5\% санаторного фонда приходится на корпоративные и ведомственные структуры. Львиную долю клиентов таким организациям обеспечивают материнские компании, что во многом снимает проблемы загрузки и развития дополнительных услуг Как правило, наряду с развитой лечебно-диагностической базой, они обзавелись высокоразвитой системой сопутствующих сервисов: питание, организация досуга, экскурсий и т. п. Дальнейшее развитие таких здравниц, с одной стороны, зависит от политики учредителей, с другой - определяется конкурентной ситуацией в данном конкретном городе или курорте.

«Мы относим себя к медицинскому оздоровительному туризму, имеем лицензию Минздрава на оказание медицинских услуг, современное оборудование, - рассказывает представитель ООО «Санаторий-профилакторий "Березка"» Д. Шмаков (г. Зеленогорск Красноярского края). - Но проблема в том, что, являясь самостоятельным юридическим лицом, санаторий арендует помещения у своего учредителя - Электрохимического завода, входящего в корпорацию "Росатом", а его щедрым хозяином не назовешь, ведь все финансирование идет через Москву, а корпорации неинтересно тратить средства на непрофильные активы. Своих сотрудников она может направлять на любые курорты, в том числе - по субсидируемым федеральным программам в здравницы Крыма, а у нас нет ни моря, ни лечебных грязей, ни минеральных вод, да и город закрытый, что накладывает свою специфику: развлечений поблизости не так много, а для иногородних клиентов приходится оформлять специальные пропуска Сегодня по контракту с материнской компанией нам поступает всего 30\% клиентов, поэтому обеспечение заполняемости - одна из самых острых проблем...

Попутные услуги, разнообразные развлечения - это вопросы себестоимости и спроса. Если у вас санаторий на 80 человек - это одно, если на 230 (наш случай) - другое. Мы - одно из трех предприятий Красноярского края, которые принимают на своей базе турнир экстремальных технических видов спорта “Короли бездорожья”; проводим дни открытых дверей, праздники - от проводов зимы до “Осеннего калейдоскопа”, устраиваем ярмарки-продажи, обслуживаем на своей территории и на выезде корпоративные 
мероприятия от семинаров до спортивных состязаний. Поддерживаем на уровне комплекс медицинских услуг, в том числе за счет ввода уникальных для региона процедур и услуг. Заключили договор со страховой компанией “СоГАЗ” о включении некоторых наших процедур в программу ДМС. Но все это - за счет собственных средств, учредитель практически не помогает. Наоборот, периодическое повышение арендной платы удорожает стоимость заезда для клиентов и осложняет нам жизнь».

Иная ситуация складывается в развитых курортных и заповедных зонах. «Благодаря целебным грязям у нас $86 \%$ излечиваемости многих профильных заболеваний (гинекология, кожные заболевания, суставы), и если наш профиль человеку подходит, он возвращается снова и снова, - поясняет А.Н. Соболева, маркетолог санатория «Химик» (г. Яровое, Алтайский край). Примерно 70\% наших больных - это постоянные клиенты. Причем не только из близлежащих регионов. Приезжают с Урала и Дальнего Востока. Зимой заполняемость составляет 70-80\%, в летний период - 100\%, причем к 150 местам в основных корпусах добавляются 50 мест в летних домиках, и в ближайшие годы планируется увеличить их количество. При этом мы стараемся не брать клиентов без лечения, не проводим никаких конгрессов, семинаров, разве что размещаем спортивные команды на летний отдых».

На политику санатория накладывает свой отпечаток соседство с г. Яровое. Популярность курорта у сибиряков послужила драйвером к развитию развлекательного, ресторанного, гостиничного бизнеса на берегах одноименного озера, так что руководство здравницы может сосредоточиться на лечебном процессе - различные сопутствующие услуги его пациенты могут получить буквально в шаговой доступности. А местные транспортные компании организовали прямые рейсы до ближайших крупных областных центров - Омска, Томска, Новосибирска.

Оставшаяся часть предприятий санаторно-курортной отрасли (около 57\%) - это коммерческие предприятия различных организационно-правовых форм. Часть из них, по сути, превратилась в пансионы и спа-отели, подстраиваясь под наиболее массовый спрос, часть продолжает функционировать по принципам медицинских учреждений, привлекая для санаторно-курортного лечения фонды предприятий и организаций и личные средства граждан, а также (в значительно меньших масштабах) средства Фонда социального страхования. Практически все организации этой группы активно развивают дополнительные услуги. Причем некоторые добиваются даже значительных успехов.

Так, весьма активно в течение последних 10-15 лет развивается курорт «Белокуриха» (Алтайский край), сделавший ставку на развитие горнолыжного отдыха в дополнение к традиционным оздоровительным программам на основе радоновых вод. В городе базируются около двух десятков санаторных организаций на пять с лишним тысяч мест, не говоря о мини-отелях, пансионатах и гостевых домах, предлагающих проживание без лечения. Развита индустрия развлечений: рестораны, клубы, боулинг-центр, два крытых аквапарка, горнолыжные трассы, экскурсионные маршруты.

По данным ЗАО «Курорт Белокуриха» (владеет санаториями «Белокуриха», «Катунь», «Сибирь»), за 2010-2014 гг. туристический поток здесь вырос со 140 до 200 тыс. человек в год, это вдвое больше, чем в советское время, при этом до $80 \%$ отдыхающих покупают путевку с лечением, остальные приезжают на отдых и корпоративные мероприятия. Это, кстати, побуждает владельцев некоторых отелей и пансионатов вводить у себя лечебно-оздоровительные услуги.

«До 2009 г. мы были SPA-отелем, но потом пришло понимание того, что в Белокуриху люди приезжают в первую очередь лечиться, - рассказывает главный врач Центра восстановительной медицины и реабилитации отеля "Беловодье" С.В. Романов. - Тогда у нас уже были свои постоянные гости. Опросив их, мы определили основные направления развития медицинского центра (хронический болевой синдром при заболеваниях спины и суставов, сопутствующие проблемы: хронические головные и тазовые боли, сколиозы и нарушения осанки, дистонии различных типов и многое другое» ${ }^{5}$.

В последние годы здесь реализуется один из крупнейших сибирских инвестиционных проектов в сфере туризма - создание туристического кластера «Белокуриха» [18. С. 5-18] В курортном комплексе «Белокуриха-2» (в нескольких километрах от «старого» курорта) частные инвесторы строят современные 
туристические комплексы и гостиницы, включая статусные отели вроде Hilton. Его главная специализация - горнолыжный курорт, но база нового комплекса будет использована в том числе и для оздоровительных направлений. По мере освоения выделенных под субкластер 136 га представители инвесторов и региональных властей не исключают возможности реализации нового проекта «Белокуриха-3».

В целом процессы, происходящие сегодня в санаторно-курортной отрасли, представляют собой продолжающийся переход от бесплатной льготной медицины к медицине, функционирующей на коммерческой основе. Развитие санаторно-курортных организаций идет бессистемно, главным критерием и направляющим вектором при этом выступают, как правило, интересы и возможности собственников. При этом мало кто из представителей медицинского сообщества сомневается в том, что если бы удалось возродить существовавшую в советские годы санаторно-курортную систему профилактики, лечения и реабилитации (естественно, на новом технологическом уровне и с поправкой на новые отношения собственности), уровень отечественного здравоохранения заметно выиграл бы, как и общий уровень здоровья населения

«Одним из важных направлений развития системы отечественного здравоохранения... является возрождение медицинской профилактики, реабилитации и совершенствование санаторнокурортной помощи. Особое место в решении этих проблем занимает санаторно-курортное лечение, представляющее собой уникальный ресурс, позволяющий обеспечить долечивание и медицинскую реабилитацию больных после специализированной медицинской помощи», - пишет заместитель гендиректора ФГБУ «Медицинский биофизический центр» им.А.И. Бурназяна ФМБА России проф. Н. Корчажкина [19].

Правда, каким образом реализовать комплексный подход к организационно-методическому обеспечению и управлению этой отраслью в новых экономических условиях или хотя бы систематизировать имеющиеся проблемы - финансирования, образования и повышения квалификации специалистов, закупки нового оборудования и т. д. - медики не представляют. Даже новые критерии отличия санаторных учреждений от спа- и иных организаций отдыха еще только разрабатываются. Так, в марте
2015 г. заместитель министра здравоохранения Т. Яковлева на международном конгрессе «Санаторно-курортное лечение» рассказала лишь о подготовке соответствующего законопроекта (не уточняя сроков) [14]. Только после принятия нового закона можно будет официально провести отбор и сформировать единый реестр санаторно-курортных учреждений, который смогут взять за основу врачи для рекомендаций своим пациентам.

Между тем время не ждет. И колебания валютного курса вопреки ожиданиям многих экспертов, вызвали не столько бум на рынке санаторно-курортных услуг, сколько сжатие платежеспособного спроса. Так, по оценке компании BusinesStat, в 2015-2016 гг. из-за кризиса в экономике следует ожидать снижения и численности потребителей, и среднего количества дней пребывания в санаториях

Кроме того, в прессе появились сообщения о сокращении финансирования курортного отдыха сотрудников некоторыми корпорациями. В частности, с января 2015 г. «Газпром» оплачивает расходы на отдых только в тех санаториях, гостиницах и на базах отдыха, которые находятся на балансе самой корпорации и его дочерних организаций. В УК «Рускомпозит» еще в 2014 г. решили полностью отказаться от программ финансирования отдыха персонала, чтобы сократить издержки [20]. Так что санаторно-курортный рынок ожидает падение как натуральных, так и стоимостных показателей, несмотря даже на рост цен. Чтобы поддержать отрасль в кризисные годы и придать ей новый импульс развития, требуются как специальные меры со стороны государства, так и умеренность в аппетитах со стороны владельцев, которым необходимо осознать преимущества долгосрочного развития перед возможностями получения быстрой прибыли.

\section{Литература}

1. Утром пляж, вечером операция // РГ URL: http://www. rg.ru/2014/08/05/turizm.html (дата обращения: 12.08.2015).

2. URL: http://www.science-education.ru/113-11205

3. Марченко О.Г. Мировой и медицинский туризм смещается в страны ATP. URL: http://www.science-education.ru/113-11205 (дата обращения: 25.07.2015)

4. Кондратьев A. Медицинский туризм: Россия или заграница. URL: http://businessofrussia.com/март/item/149-medturizm.html (дата обращения: 11.08.2015). 
5. Медицинский туризм в России. URL: http://www. lifeintravel.ru/stativse-obo-vsem/meditsinskiy-turizm-v-rossii

6. ЭКО в России. URL: http://www.9months.ru/press/7-8/10/ (дата обращения: 21.08.2015)

7. URL: http://www.treatment-abroad.ru/tourism/russia_globalmedicaltourism/16566

8. Кувшинов М. А. Трудовая миграция: до цивилизованных отношений еще далеко // ЭКО. - 2013. - № 6. - С. 168-180.

9. Лукьянчук Е. Пациенты без границ. URL: http://pharmapractice. ru/50607 (дата обращения: 21.08.2015).

10. Мамонова Е. В. Медицинский технопарк: новые возможности для развития инновационных проектов // ЭКО. - 2013. - № 9. - С. 15-28. 11. Лабин А. Новый шанс для концессий. URL: http://expert.ru/ expert/2015/23/novyij-shans-dlya-kontsessij (дата обращения: 21.08.2015).

12. URL: http://www.ksonline.ru/stats/-/id/3276/ (дата обращения: 30.09.2015).

13. URL: http://pharmapractice.ru/72100.

14. Число мест в санаториях России превысило советские показатели // Ведомости. URL: http://www.vedomosti.ru/business/ articles/2015/04/29/chislo-mest-v-sanatoriyah-rossii-previsilo-sovetskiepokazateli (дата обращения: 14.08.2015).

15. Лето 2015: взрывного роста внутреннего туризма в России нет. URL: http://www.atorus.ru/news/press-centre/new/32650.html

16. Данн В. Э. Развитие туристической отрасли пущено на самотек // ЭКО. - 2015. - № 9. - С. 30-37.

17. URL: http://www.belovodie.su/news/main/2012/07/12/62/ (дата обращения: 14.10 .2015$)$

18. Веселова Э.Ш. Туризм: мобилизовать внутренние резервы // ЭКО - 2015 - № 9 - С 5-18.

19. Корчажкина Н. Совершенствование системы санаторно-курортного лечения в Российской Федерации // Медицина. Целевые проекты. URL: http://www.sovstrat.ru/journals/medicina-celevye-proekty/articles/ st-med16-27.html (дата обращения: 05.10.2015).

20. Горелова Е. Патриотический отпуск // Ведомости - 2015. № 3908. - 2 сент.

Подготовила кор. «ЭКО» Э.Ш. ВЕСЕЛОВА 